Relations industrielles

Industrial Relations

\title{
A U.S. Commentary
}

\section{Solomon Barkin}

Volume 44, numéro 4, 1989

URI : https://id.erudit.org/iderudit/050540ar

DOI : https://doi.org/10.7202/050540ar

Aller au sommaire du numéro

\section{Éditeur(s)}

Département des relations industrielles de l'Université Laval

ISSN

0034-379X (imprimé)

1703-8138 (numérique)

Découvrir la revue

Citer cet article

Barkin, S. (1989). A U.S. Commentary. Relations industrielles / Industrial Relations, 44(4), 905-914. https://doi.org/10.7202/050540ar
Résumé de l'article

A U.S. Commentary
Tous droits réservés (c) Département des relations industrielles de l'Universite Laval, 1989
Ce document est protégé par la loi sur le droit d'auteur. L'utilisation des services d'Érudit (y compris la reproduction) est assujettie à sa politique d'utilisation que vous pouvez consulter en ligne.

https://apropos.erudit.org/fr/usagers/politique-dutilisation/ 


\section{A U.S. Commentary}

\section{Solomon Barkin}

In publishing this silver anniversary volume the editors and the Canadian Industrial Relations Association have produced a competent, readable, skillfully edited, noteworthy and useful volume of outstanding value to students of industrial relations anywhere. Indeed, they have provided a prototype for volumes to be published on the same subject in other countries. This volume consists of two parts, though they are not denoted as such. The first includes the introductory and concluding chapters by the editors defining their major goals and posing the question as to whether industrial relations is a multidisciplinary field of study, an academic discipline or a practicing art. The second part comprises eight chapters dealing with six disciplines by specialists in each who review academic writings on selected subjects, with special emphasis on those of recent date, and who appraise the impact of their discipline on the study of industrial relations and in several cases, its reciprocal influence on their disciplines. Relying primarily on the printed word, the authors' discussions reflect the range of considerations and issues treated by academics in the field but rarely the subjects beyond these limits. Two chapters are assigned to history and law. One deals with Québec and the other with Canadian writings. Conceived by specialists, the chapters focus strictly on their fields with but occasional reference to others. The bibliographical notes are extensive, making the chapters veritable guides to the subjects.

An old adage must be altered in the case of this book. The sum of the parts (chapters) is greater than the whole itself. The concluding chapter deals primarily with the authors' observations relating to the questions raised in the introductory chapter and offers no integrated summary of its contents. The reviewer believes that if the undertaking is to be completed additional chapters need to be issued. Only then will the editors and readers reach a definitive conclusion as to the category to which the field of industrial relations should be assigned.

\section{INDUSTRIAL RELATIONS - WHICH CATEGORY OF ACADEMIC ENDEAVOR?}

Having initiated the inquiry in part to determine whether industrial relations should be conceived as a multidisciplinary field of study, a discipline or a practicing art, the editors warn the reader that author adhered «to the view he liked best» (p. 6). They conclude that «it is most likely that [the reader at the end] still has the idea he had before opening this book» (p. 287). In their view the purpose of this book is not to settle the debate. It may never be settled for «there is no final word on this question, except that, however fascinating it may be, it is not a problem that has to be resolved in any urgent manner» (p. 288).

* BARKIN, S., Professor, University of Massachusetts at Amherst, Mass., U.S.A. 
But the original question cannot be set aside for an answer will provide quidance on the scope, methodology and questions to be asked. The latter can guide the Association in its endeavors and the members in getting assistance in their practice. Actually, the editors offer a significant key in response to their initial query. At the end of the book they exhort academics of «as many social science disciplines as possible - economic, behaviourist, legal, management, ethical, political, and in as many contexts as possible geographical, political, social, ethnic and sexual environment» to continue their studies for «the main condition to fully understand the problems we are seeking to analyze in a multidisciplinary approach» (p. 290). They add that «our study subject is as complex and changing as human beings in their social and economic relationships» (p. 290).

If the above is our guide, and the current reviewer has considerable sympathy with this view, one must extend the range of subjects to the cultural sciences such as cultural anthropology, the labor and employee groups and their dependents, including their attitudes, behavior and activities both in and out of the workplace, philosophy, the disadvantaged, and the many forms of individual and social protest which will help us understand the behavior of the working groups ${ }^{1}$. We have become increasingly concerned with other social systems such as those of medical and child care which impact and affect working groups particularly as employers are beginning to address the high costs of supplying these aids and protection and using them as recruiting incentives. More attention should also be paid to the diverse forms of protest rather than restrict studies to more overt types such as strikes, high labor turnover, grievance rates and slow downs. Labor and management political activities have been almost entirely neglected. Practitioners of industrial relations in the workplace must be prepared to deal with all evidence of discontent, better to advise or devise policies and programs for meeting these challenges.

In asking if industrial relations is an art the editors perform a notable service to the field by highlighting that a significant part of the membership is composed of practitioners acting for unions, management or government or as individual consultants. Their insights can prove of inestimable value, but their experience has been inadequately tapped in academic studies. They produce the grist of the mill of events recorded in the annals of industrial relations.

In inviting a broadened range of people in different fields and with varied experience to participate in our academic pursuits, we can curb the predilection of academics to formulate sweeping conclusions and «laws» on which to base policy and practice without looking at the complexity of the phenomena, the diversity of situations and significance of newer elements operating with the passing of time in supposedly familiar circumstances.

1 Ralph L. BEALS, Harry HUIJER and Alan R. BEALS, Anthropology, 5th edition, New York, MacMillan Publishing Company, 1977, pp. 9-10; pp. 337-374; pp. 423-472; pp. 631-660; Conrad M. ARANSBERG and Arthur H. NIEHOFF, Social Change, Chicago, Akdube and Atherton, 1971, pp. 263. 


\section{THE SIX DISCIPLINES}

The direct evidence supplied by the book is contained in the individual chapters for the six disciplines. Each demands its own review as the presentations do not lend themselves to an integrated treatment. The chapters will be considered in two groupings, those with a single theory including industrial relations, economics, management theories and behavioral sciences and those which primarily follow a historical course.

\section{Industrial Relations}

In the first category we place the chapter on «mainstream industrial relations». The author, Professor Alton W.J. Craig offers a «framework for analyzing industrial relations systems». Building on John Dunlop's scheme, itself derived from Talcott Parsons' structural-functionalist view of social institutions, he sheds it of its theoretical orientation and converts it into a technique for arranging industrial relations facts «in order» and for deriving «direction» (p. 39). This view lends itself to expansion beyond the subsystems which Dr. Craig employs, thereby allowing for the introduction of dynamic forces into what had been essentially a static model. He himself adds the dimension of «technology» which in our current environment is already essentially dynamic. Presumably, it is the author's academic bias which prompts him to exaggerate the potentially dynamic qualities of the «practitioners and researchers conscious [...] need to be aware of what is happening in the environment and its potential effect upon the system in operation or under study» (pp. 38-39). Truly, more volatile subverting forces need to be injected to reach the catalytic effects for realizing change. Having progressed so far in stripping the field of its static ideological biases, it should not take much to pursuade the author to drop the title «system analysis» and label it «a structural plan for data analysis», thereby enabling researchers to have the complex phenomenon more adequately mirrored in the charts. The value of this simplification will become more evident in the discussion of the chapter on «economics».

\section{Labor Economics}

Here Professor Morley Gunderson discusses several prominent «alternative theoretical perspectives» in the discipline, but concentrates almost exclusively on neoclassical logics and the works of economists steeped in this tradition. He stresses the necessity of incorporating tests of economic efficiency and costs and causal factors in the discussion of policy choices and practices. The aim is to achieve an efficient management. Other economic, ethical, environmental and social goals have no place in this examination - critical omissions for the study of industrial relations ${ }^{2}$.

2 For an up-to-date and rounded presentation of institutional economics see Allan G. GRUCHY, The Reconstruction of Economics, Westport, Connecticut, Greenwood Press, 1987, pp. 168; for a discussion of the similiarities of unionists' and institutional economists' views, see Solomon BARKIN, «Institutional Economics and the American Trade Union Movement», Relations Industrielles, Vol. 43, No. 3, 1988, pp. 498-525. 
This chapter on economics is based on one basic assumption and one disposition of practitioners of the neoclassical system of thought. The assumption is that the society and economy tend to seek an equilibrium, thereby denying or minimizing a continuing state of disequilibrium of varying magnitudes which national policy makers often try to rectify. The tendency is to concentrate on the general direction of movements and to subordinate the concern for divergent trends, instability and unrest. Absorbed in this study of measurements of economic phenomena they often may disregard non-monetized and/or non-quantitative data in their search for mathematical precision thereby often failing to penetrate the real meaning and nature of events. They prefer questionable accuracy to deeper insight. These deficiencies have been particularly fatal in periods of great change and economic and social turbulence and in the study of the complex events found in industrial relations. It is therefore not surprising that among the early dissenters from the neoclassical tradition have been those economists who have studied and concerned themselves with social and industrial relations problems. While these approaches are represented in the writings in other social sciences it is nowhere else as dominant as in the economic discipline.

The author questions the wholesomeness of the extensive use of mathematics in the social sciences for it «may also increase the risk of errors not being detected behind the formidable mathematics [and] may lead to focussing on problems that are conducive to mathematical techniques rather than on problems of important social concern, it reduces the use of common sense reasoning, and it reduces communication across other disciplines that do not rely so extensively on mathematics. The latter may be of particular concern to industrial relations where mathematics is conventionally not regarded as a necessary tool» (p. 53). The author therefore argues for a synthesis of labor economics and industrial relations through "cross-fertilization" (p. 69) and for the economist to «endogenize the institutional restraints» in their analysis (p. 54). He also concludes that the economist must gain «an appreciation of the role of alternative mechanisms to the labor market (namely, collective bargaining and legislation) for achieving the same ends, and an appreciation of the historical and legal context in which institutional arrangements exist, as well as the importance of the process of achieving certain outcomes - issues that are all emphasized in industrial relations» (p. 69).

Special note must be made of the glaring obsolescence of many writings in the field of wages and employee compensation and the multiplication of the states of employment. As for compensation many new forms of rewards and aids are being offered employees by their employers often resulting directly from labor management agreements or by public authorities. These have made the simplistic concepts of the money wage rather deceiving. (In Europe the term «social wage» has gained favor to cover many of the public 
benefits ${ }^{3}$.) Similarly, new forms of peripheral employment have introduced new forms of attachment or non-attachment to the firm, varying durations of work, and compensation and benefits ${ }^{4}$.

\section{Management-Industrial Relations Interface}

The third restricted discussion is provided in the chapter on «Management-Industrial Relations Interface». It concentrates on the discussion of management theories. Traditional ones of corporate governance exclude or sharply subordinate the industrial relations dimensions from their views. But the authors see mounting evidence of the recognition of a need for fundamental revamping of these views. The pressure is emerging from many sources but they particularly stress the imminent transformation in the service industries, particularly those employing large numbers of professional staff. They conclude that «we are now entering an era in which management increasingly regards its work force as a resource rather than a cost. To a greater degree than ever before, organizations know that their survival depends on a close collaboration and genuine willingness to collaborate on all side. "[...employees] are asking to be full partners, and, as partners, they are no longer shy about insisting upon having a voice in shaping the organization's strategic orientations) (p. 182). May we add that this summation and projection represents a far cry from the conclusions drawn by the U.S. human resources management advocates 5 .

Furthermore, the authors offer evidence of support for this reexamination of management policies from recent contributions in management theory. The American school views «organization as a battleground of multiple and conflicting goals, where conflicts must be sorted out through negotiation» (p. 166). French theorists visualize the organizations as political systems and serve as forums «in which the various actors, or partners to the interactions, exert their power in pursuit of gain» (p. 167). While these views have not percolated down to the level of practical discussions managements in the United States have resorted to more use of employee suggestions for greater efficiency at the shop level, without yielding power

3 Solomon BARKIN, «The Total Labor Package: From Wage Bargain to Social Contract», Journal of Economic Issues, Vol. XI, No. 2, June 1977, pp. 339-351; see also for analysis of non-monetized costs and benefits: Bent ANDERSEN, Work or Support: An Economic and Social Analysis of Substitute Permanent Employment, Paris, OECD, 1966, pp. 124 and Solomon BARKIN, «The Economic Costs and Benefits, and Human Gains and Disadvantages of International Migration", Journal of Human Resources, Vol. II, No. 4, Fall 1967, pp. 495-516. In way of contrast, economists tend to limit their study of fringe benefits to those financed by employers and take no account of employee costs and benefits, particularly nonpecuniary ones.

4 Solomon BARKIN, «The Flexibility Debate in Western Europe: The Current Drive to Restore Management Rights over Personnel and Wages», Relations Industrielles, Vol. 42, No. 1, 1987, pp. 12-45.

5 Solomon BARKIN, «Human Resources Management Examines itself and its Limitations", Relations Industrielles, Vol. 44, No. 3, 1989, pp. 691-702. 
strategic decision making. Nevertheless, cost or tax considerations have enticed employers to offer Employee Stock Ownership Plans, without granting employees in most cases any more rights to participate in decision making $^{6}$. Unions and management in European countries have made greater progress in the latter direction. The authors conclude their chapter on an optimistic note: «Clearly, a new balance of power is in the making. It is even possible that, in time, human resources will actually become the principal focus of strategic concerns; i.e., human resources will no longer be a subordinate concern or dependent dimension, but rather that which makes the attainment of other strategic goals possible» (p. 182).

Concentrating as this chapter does on management theories, it omits actual management practice in the field of industrial relations. Many observers have noted that the Canadian experience with unionism and collective bargaining has been more favorable to both institutions than in the United States, despite the considerable American ownership of Canadian corporations. An estimate for December 1984 places the membership at 3867 million workers and the penetration rates at 41,4 percent of the nonagricultural workforce. The estimate of overall collective bargaining coverage is 46,5 percent $^{7}$.

Among the major causes for this difference in experience has been Canadian managements' lower level of unfriendliness to unions and a disposition to deal with them. This conclusion is corroborated by a recent study of management policies and initiatives in the eighties. The authors conclude that the policies «differed substantially from the United States developments. While the United States managers worked to develop a parallel non-union employment system, Canadian managers worked largely within collective bargaining to seek such changes that addressed market demands. This conduct of Canadian managers has been shaped by important environmental influences such as geography, the legal framework and its enforcement and the strength of the labor movement [...] The independent choice and judgment of Canadian managers to opt for this approach has also been important [...] Managerial choices have contributed to a decline of the collective bargaining system in the U.S. while it has the opposite effect in Canada ${ }^{8}$.

\section{Behavioral Sciences}

Professor John B. Kerwin keenly and sensitively distills the findings of the behavioral scientists (social psychology and sociology) respecting unions, technological change, collective bargaining and strikes. Concentrating on individual, group and organizational behavior, the presentation

6 Christopher FARRELL and John HOERR, «ESOPs: Are They Good For You?», Business Week, May 15, 1989, pp. 116-123.

7 Pradeep KUMAR, «Estimates of Unionism and Collective Bargaining Coverage in Canada», Relations Industrielles, Vol. 43, No. 3, 1988, pp. 757-778.

8 Anil VERMA and Mark THOMPSON, «Managerial Strategies in Canada and the U.S. in the 1980s», paper delivered at the Annual Meeting of the Industrial Relations Research Association, New York, April 29, 1988. 
contrasts sharply with the earlier American and European sociology concerns at the societal levels and social movements. His focus is on the impact of individual differences in personality traits and social characteristics and social norms and structures. He summarizes same in the following sentence: «behavioural science research often focusses on the 'how?' or 'why?' aspects of a causal relationship, rather than identifying significant variables that predict the outcome» (p. 190).

The cumulative effect of the abundant recital or research findings is to leave the reader more knowledgeable but troubled. The author makes it clear that writers follow diverse approaches in their work. The subjects also shift with the tides of public debates and academic concerns. Earlier findings are often countered by later ones. No tests are mentioned of the applicability of national results to other countries. In the case of attitude and opinion surveys and interviews special attention must be addressed to whether the questions truly formulate the issues being studied or whether the proxies are related to the phenomenon being examined. We know that all too often investigators are not adequately steeped in the issues. Do the answers to questions truly reflect the respondents' views or are they defensive in nature, a characteristic not uncommon among subordinate economic and social groups ${ }^{9}$. In view of the limitations in the nature of these findings, it is certainly useful for authors of summaries of views to provide annotated critiques on the reliability and usefulness of conclusions they report. In view of the fact that these findings are largely sought to apply to practical conditions and problems, the author could have contributed substantially to his presentation if he had discussed the art and practice of such application. This guidance would contribute substantially to the use of the material and the scholars' sensitivity to the exacting tests to which the results will be put ${ }^{10}$.

\section{History}

We shall now consider the two disciplines which are dealt with in a somewhat more historical manner. The two chapters on history offer guides to the existing literature and reflect the limitations in the current state of the discipline. Because historical materials are essential to the understanding of past events, one must support the authors' pleas for more extensive collections of basic materials and intensive studies to provide a more confident base for depicting past patterns of development of the life and conditions among employees as well as their organizations and activities. While unions to some degree have recognized the usefulness of such records and sponsored the collection of materials and some studies, Canadian employers

9 Solomon BARKIN, «Evaluation of Recent Research on Employee Attitudes and Morale», Proceedings of the 4th Annual Meeting of the Industrial Relations Research Association, 1951; for a prototype study of the behavior patterns of workers see Ferdynand ZWEIG, The British Worker, London, Penguin Books, 1952, pp. 243.

10 For a classic book on interdisciplinary analysis of industrial relations issues see: A. KORNHAUSER, R. DUBIN and A.M. ROSS (editors), Industrial Conflict, New York, McGraw-Hill, 1954, pp. 327. 
have been more derelict in this regard than U.S. employers. Professor Desmond Morton offers a helpful classification of the schools of historians. The reader would have benefited from a sharper contrast between Québec writings and others, and the respective influences which affected them. Most revealing is the discussion of the academic and political coloration of the authors in different periods enabling the reader to discern the influences affecting their choice of subjects and the cast of their products. Particularly, we note the significant leftist and labor sympathies among the postwar historians and their effect on the nature of their work.

Among the many gaps in the historical work which call for much investigation is the influence of ethnic and national origins on the responses to union recruitment efforts and degree of participation in union administration. Would studies of the upsurge of postwar white collar unionism confirm the thesis that it was associated with the entry of children of the British migrants to Canada of earlier decades of the century ${ }^{11}$ ?

\section{Law}

One central issue found in the two chapters on law is the discord created by the coexistence in the field of industrial relations of two incompatible systems of thinking. On the one hand is the simplistic individualistic credo of the law and on the other hand, the collectivistic orientation of trade union activities, philosophies and programs. Though this issue is of long standing, the tension between the two has been intensified with the adoption of the 1982 Canadian Constitution with its enumerated Charter of Human Rights and the Québec Civil Code. A central question is how will the Supreme Court ultimately accommodate the two distinct outlooks. Will it craft an integrated system to reconcile the two and, if so, what guides will it employ? In the past, the process of adjustment occurred in a piecemeal fashion through individual pieces of legislation, administrative and judicial rulings, specific agreements between the parties at interest and the weight of practice. No total reconciliation was realized. Exceptions were granted under the basic law to meet specific needs within the industrial relations field. But in other fields no such overt reconciliation occurred in law, but some industrial relations practices were allowed to continue unchallenged. The collectivistic union approach therefore entrenched itself into the system and gained sanctions through practice. Will this pragmatic attitude continue to prevail or will the Supreme Court venture to unify the systems and if so, will these answers survive the disapproval if not resistance from the economic institutions?

It is in recognition that the handling of these issues is fraught with considerable public danger that the authors and other leaders have urged legal

11 George Vickers HAYTHORNE, «Canada: Postwar Changes and Current Ferment», in Solomon BARKIN, Workers Militancy and its Consequences, New Directions in Western Industrial Relations, New York, Praeger Publishers, 1975, pp. 327. A necessary section should be one on the history of industrial relations writings in Canada. A current contribution is an article by Anthony GILES and Gregor MURRAY, «Toward and Historical Understanding of Industrial Relations in Canada», Relations Industrielles, Vol. 43, No. 4, 1987, pp. 780-810. 
professionals to familiarize themselves with the knowledge and insights gained by the different cognate disciplines. They insist that the law cannot remain isolated from other fields in the study of industrial relations.

Though the legal framework of the U.S.A. industrial relations system has had a profound effect on the Canadian system, many significant differences have emerged. Scholars have proposed considering individual items for incorporation into American practice, particularly in respect to the certification of bargaining agents and the conclusion of an initial contract between the parties at interest. Canada has ratified most conventions of the International Labor Organization, whereas until very recently the United States has not. What has been the experience with this process and its effect on Canadian practice? More in-depth studies than are now available would be useful to guide American policy.

The authors underscore the contributions which law has and can in the future make in universalizing social goals, including due process, equality, equity, impartiality and justice. Professor Bernard L. Adell's chapter also defines some unsettled issues in Canadian law such as the application of majoritarianism and exclusivity in the designation of union representation for an individual bargaining unit.

\section{FINAL OBSERVATIONS}

Two final observations on this compilation of papers on the contributions of six disciplines to the understanding of the Canadian industrial relations system appear essential. The first relates to issues noted sporadically through the chapters, particularly industrial relations and the law. Few writers describe in any detail the distinctive characteristics of the Canadian industrial relations system or contrast it with the United States and Great Britain though free use is made of the literature from these countries. The second derives from the fact that of the ten authors, five have received their professional training in the United States, three, in Canada and two, in Great Britain. The individual chapters reflect a close knowledge of the U.S. literature, make selective but limited use of British writings and offer less than a handful of references to French publications. In view of the preponderant use of U.S. data with its distinctive slants in this field, it behooves scholars to develop and refine their statements on the characteristics of the Canadian system to be of even greater assistance in shaping a system which is most responsive to the national cultural and aspirational settings in this country.

This volume will serve as a point of departure for future studies in many fields of industrial relations. As suggested it must be complemented by additional studies of other cognate fields and on such issues as have been raised in this review. One significant challenge must be dealt with relates to the preponderant disposition of the individual disciplines to build their theoretical systems and inquiries around assumptions of inherent tendencies to realize equilibria. This predilection handicaps each of the disciplines in serving the industrial relations field in which dynamism and change are ever driving forces. The addition of dynamic dimensions to the prevailing static 
ones will permit the academic research field to better serve the needs of the practitioners as well as enrich the theoretical field. The efforts of the past in this endeavor must be rejuvenated by new ones. More profound and encompassing analyses are needed of the Canadian system to permit its participants and students better to understand and appreciate its distinctive characteristics, innovations and trends.

\section{Un commentaire européen}

\section{Dimitri Weiss}

Il n'est pas sans intérêt de noter que la parution de ce volume à l'occasion du XXV' anniversaire de l'Association canadienne des relations industrielles, intervient juste trente ans après la publication de Industrial Relations Systems par John T. Dunlop, comme pour faire le point de l'évolution des idées au bout de trois décennies que certains avaient, pratiquement, perçues comme un règne sans partage.

Il est certain que $L$ 'état de la discipline en relations industrielles au Canada est un ouvrage qui trouvera sa place sur la même étagère que le monumental Dictionnaire canadien des relations du travail de Gérard Dion - objet, justifié, de la première ligne et de la première référence, page 1 du chapitre $\mathrm{I}$ - au titre des contributions majeures du Canada à l'intelligence de notre domaine commun. Car sa portée, à l'instar de l'oeuvre de Dion, dépasse visiblement les frontières du pays, fussent-elles impressionnantes, pour investir l'Amérique du Nord dans son ensemble et nous fournir des enseignements et des observations utiles pour notre propre situation - je parle en tant qu'européen -, dont l'évaluation reste, en partie, tributaire des pensées du Nouveau Monde.

Notre domaine commun, ai-je dit, ne signifie pas uniquement celui des Américains, des Européens et des autres, mais aussi - et surtout - de tous ceux qui, à partir des domaines disciplinaires d'apport traditionnels - économie, droit, sociologie, psychologie, histoire, sciences politiques - à ceux de plus récente pénétration dans nos préoccupations majeures - le management, la gestion - et aux chercheurs qui en ont une approche transdisciplinaire ou transversale, se sentent partie prenante d'un champ, d'une discipline ou d'une multidiscipline, dont ils se réclament avec une égale force.

Dans la cinquième édition des Relations du travail: employeurs, personnel, syndicats, État, (Dunod, 1984 (1983), p. 10), j'avais pour ma part observé combien l'exigence d'un échange entre optiques et méthodologies diverses avait été accompagnée d'une ouverture de chacune des disciplines composantes vers d'autres, avec lesquelles s'établissent des liaisons et des

* WEISS, Dimitri, professeur, Université de Paris, Panthéon-Sorbonne, Institut d'Administration des Entreprises. 